\title{
FATTY ACID COMPOSITION OF CATFISH (Clarias gariepinus) VISCERA OIL
}

\author{
EFFIONG, B. N. and J. O. FAKUNLE \\ Federal College of Freshwater Fisheries Technology, New Bussa.
}

Copyright 2010, Fisheries Society of Nigeria.

This paper was prepared for presentation at the $25^{\text {th }}$ Annual International Conference and Exhibition in Administrative Staff College of Nigeria (ASCON), Topo-Badagry, Lagos, Nigeria, $25^{\text {th }}-29^{\text {th }}$ October, 2010.

This paper was selected for presentation by an FISON Program Committee following review of information contained in an abstract submitted by the author(s). Contents of the paper, as presented, have not been reviewed by the Fisheries Society of Nigeria and are subject to correction by the author(s). The material, as presented, does not necessarily reflect any position of the Fisheries Society of Nigeria its officers, or members. Papers presented at FISON Society of Nigeia, its officers, or members. Papers presented at FISON Fishies Society of Nigeria. Electronic reproduction, distribution, or storage Fisheries Society of Nigeria. Electronic reproduction, distribution, or storage of any part of this paper for commercial purposes without the written consent of the Fisheries Society of Nigeria is prohibited. Permission to reproduce in print is restricted to an abstract of not more than 300 words; illustrations may not be copied. The abstract must contain conspicuous acknowledgement of where and by whom the paper was presented. Write Librarian, Fisheries Society of Nigeria (FISON), P. O. Box 2607 Apapa, Lagos.

\section{ABSTRACT}

The fatty acid composition of oil extracted from the viscera of African catfish, Clarias gariepinus caught from a fish farm in New Bussa was investigated with a view to prove their usefulness. A total of 20 fatty acids were obtained out of which five were identified. Lauric, Palmitic and Stearic acids were the main saturated and monounsaturated fatty acids respectively. The principal acids in the polyunsaturated group were Oleic and Linoleic acids. C. gariepinus viscera is constituted of polyunsaturated fatty acids which make it a valuable pharmaceutical raw material rather than waste.

\section{INTRODUCTION}

A great deal of attention has been recently paid to the various health benefits apparently associated with the consumption of fish rich in fish oil. Health benefits appear to be associated with the presence of high levels of the n-3 family of polyunsaturated fatty acids (PUFA) also called Omega-3 fatty acids such as eicosapentaeonoic acid (EPA) and docosahexanoic acid (DHA) (Neil, 1997). Oily fish and fish oil supplements aid in the prevention and management of coronary heart disease (CHD), (Minnis et al., 2006). Omega-3 fatty acid enriched seafood products are effective in lowering serum triglycerides and blood pressure (Inga-Britt et al., 2004). They help in reducing the risk of developing an abnormal heart beat that can lead to heart problems and even sudden death. Catfishes of the family claridae comprise the most commonly cultivated fishes in Nigeria. The growth of aquaculture in Nigeria is now largely being boosted by the steady rise in catfish culture (Oresegun et al., 2007).

The by-products of catfish processing consists of frames and viscera which are often thrown away. Viscera from catfish are an abundant and underutilized by-product that could be used as a unique lipid source (Sathivel, et al., 2003). From the foregoing therefore, this experiment was conducted to determine the fatty acid composition of oil extracted from catfish (Clarias gariepinus) viscera.

\section{MATERIALS AND METHODS}

Live catfish (Clarias garepinus) were harvested from a private fish farm in New Bussa, Niger State, Nigeria. The viscera were collected as the fish samples were being prepared for smoking by fish processors. A total of $2 \mathrm{~kg}$ of viscera from 70 fish samples with average weight of $500 \mathrm{~g}$ were collected and stored at $-5^{\circ} \mathrm{C}$. Extraction of the crude oil was carried out at the Analytical laboratory, National Institute for Freshwater Fisheries Research (NIFFR), New Bussa using the method of Stewart et al. (1974). The extracted oil of about $250 \mathrm{ml}$ was stored at ambient temperature before taken to the Central Science laboratory, 
Obafemi Awolowo University, Ile-Ife, Nigeria for fatty acid determination.

The fatty acids were converted to their methyl esters and heptanes according to the method of Christie (1997). About $5 \mathrm{ml}$ of the oil was esterified with acetone (59:41). The reaction mixture in vials was heated at $80{ }^{\circ} \mathrm{C}$ on hot plate for $30 \mathrm{~min}$, cooled and then diluted with water, extracted with diethyl ether and analysed by high pressure liquid chromatography (HPLC). Identification and quantification of fatty acids were carried out in HPLC using the methods of Christie (1997). Reference standards which had been developed with use of application of HPLC overtime was used to identify the components using relative retention time. A total of five fatty acids for which reference standards were available were identified.

Percentage composition of each fatty acid identified was calculated using peak area as follows:

$\%$ Fatty Acid $=$ Peak area of sample $\mathrm{x}$ conc. of std. $x$ dilution factor

Peak area of standard

\section{RESULTS AND DISCUSSION}

The profile and percentage composition of the 5 different fatty acids identified from the catfish (Clarias gareipinus) oil is presented in Table 1. Lauric acid was the dominant (37.24\%) followed by Linoleic acid (13.52\%). Oleic acid was low (6.04\%) while Myristic acid was absent. The low content of Oleic acid may be attributed to the poor quality of feed fed to the fish. Satoh et al., (1989) reported that diet had a major effect on the fatty acid composition of lipid. Linoleic acid was the dominant polyunsaturated fatty acid $(13.52 \%)$. This finding is similar to the reports of Ollis et al., (1999) and Satthivel (2009). Polyunsaturated fatty acids (PUFAs) are known to prevent/reverse insulin resistance by decreasing TNF- $\alpha$ levels and possibly by enhancing adiponection levels. This PUFAs are likely to be useful in preventing ad/or reversing some of the side effects of retroviral drugs. Das (2006) reported that direct intake of various PUFAs alters the cell membrane fatty acid composition, which in turn, modulates cell/tissue response to infection, injury and inflammatory actions.

\section{CONCLUSION}

From the findings of this experiment, catfish (C. gariepinus) viscera rather than being wasted as it is presently done by most fish processors around Lake Kainji (New Bussa) could be a rich source of PUFAs which could also be of immense health benefits to consumers.

\section{REFERENCES}

Christy, W.W. (1997). Structural Analysis of fatty acids. Advances in Lipid Methodology. Pp119-167.

Das, U.N. (2006). Essential fatty acids: Biochemistry, physiology and Pathology. Biotechnology. J. (1): 420-439.

Inga-Britt, G.; Margaretta, O; B.O. E. and Bergt, V. (2004). Moderate amounts of n-3 fatty acid enriched seafood products. Journal of Human Nutrition and dietetics 17(5): 490499.

Minis, R., Haq., I; Jackson, P.R; Yeo, W. and Ramsay, L. (2006). Oily fish and fish oil supplements in the prevention of coronary heart disease. Journal of Human Nutrition and Dietetics (5): 449-459.

Neil, J.S. (1997). Fish consumption, fish oils and coronary heart disease. The American Journal of clinical Nutrition 65:1083-1086.

Ollis, T.E. Meyer, B.J. and Howe, P.R. (1999). Australian food sources and 
intakes of Omega-6 and Omega-3 polyunsaturated fatty acids. Ann. Nutri. Metab. 43: 346-355.

Oresegun, A; Oguntade, O.R. and Ayinla, O.A. (2007). A review of Catfish culture in Nigeria . Nig. J. fisheries 4(1): 27-52.

Sathivel, S; Witoon, P.; Joan, M. and Casay, C. (2003). Oil production from catfish viscera. Journal of American oil chemists society. 80 (4): 377-382.
Sathivel, S; Yin, H and Prinyawiwatkul, W. (2009). Comparison of chemical and physical properties of catfish oils prepared from different extraction processes. Journal of Food Science. 74(2): E70-E76.

Satoh, S; Poe, W.E. and Nelson, R.P. (1989). Effect of dietary n-3 fatty acid on weight gain and liver pobr. Fatty acid composition of fingerling channel catfish J. Nutr. (1) 19-23.

Table 1: Fatty Acid composition (\%) of Clarias gariepinus viscera oil

\begin{tabular}{ll}
\hline Fatty acid & \% Composition \\
\hline Lauric acid & 37.24 \\
Oleic acid & 6.04 \\
Palmitic acid & 12.86 \\
Linoleic acid & 13.52 \\
Steoric acid & 1.32 \\
Myristic acid & - \\
\hline
\end{tabular}

